\title{
Solar retinopathy without abnormal exposure: case report
}

\section{Retinopatia solar sem exposição anormal: relato de caso}

\author{
Ricardo Alexandre Stock ${ }^{1}$, Simone louise Savaris ${ }^{2}$, Erasmo Carlos Rodrigues de Lima Filho², Elcio Luiz Bonamigo ${ }^{1}$
}

\begin{abstract}
Solar retinopathy is photochemical damage to the retina, usually caused, by direct or indirect solar observation resulting from the use of hallucinogenic drugs, mental disorders or during eclipses. There may be a loss of visual acuity. We report the case of a 38-year-old patient who presented with a clinical diagnosis of solar retinopathy in the left eye, no prior history of sun exposure, normal visual acuity and complaints of metamorphopsia. Optical coherence tomography showed a rupture of the retinal pigment epithelium, confirming class II solar retinopathy. Visual acuity tends to normalize after 3 to 9 months, but not always. Thus, there is a real need to educate people about using eye protection during sun exposure especially given that some people may be highly susceptible to retinal damage, which was presumably the case for this patient. Finally, we note the importance of optical coherence tomography in diagnosing solar retinopathy.
\end{abstract}

Keywords: Retina/pathology; Sunlight/adverse Effects; Visual Acuity/radiation effects; Retinitis/etiology; Tomography, optical coherence/classification; Case report

\section{RESUMO}

Retinopatia solar é o dano fotoquímico à retina causado, geralmente, pela observação solar, direta ou indireta, devido ao uso de drogas alucinógenas, distúrbios psíquicos ou durante eclipses. Pode haver, ou não, perda de acuidade visual. Relata-se o caso de uma paciente, 38 anos, com quadro de retinopatia solar em olho esquerdo, sem história prévia de exposição solar, apresentando acuidade visual normal e queixa de metamorfopsia. A tomografia de coerência óptica mostrou ruptura do epitélio pigmentar da retina, confirmando retinopatia solar padrão II. A acuidade visual tende a normalizar-se entre 3 a 9 meses, mas nem sempre. Assim, enfatiza-se a necessidade de orientação à população sobre proteção ocular durante exposição solar pela possibilidade de existirem pessoas com susceptibilidade elevada ao dano retiniano, como se presume possa ter ocorrido com esta paciente. Finalmente, destaca-se a importância da tomografia de coerência óptica para o diagnóstico da retinopatia solar.

Descritores: Retina/patologia; Luz solar/efeitos adversos; Acuidade visual/efeitos da ra diação; Retinite/etiologia; Tomografia de coerência óptica/classificação; Relato de caso

\section{INTRODUCTION}

Solar retinopathy, also known as photomaculopathy, eclipse retinopathy and foveomacular retinitis, is retinal damage resulting from direct or indirect solar observations during a solar eclipse or on a normal day ${ }^{(1)}$. Light can damage the retina via mechanical, thermal or photochemical means, either alone or in combination. Photochemical damage (actinic) occurs during prolonged low irradiance exposure that lasts more than 10 seconds $^{(2)}$.

Retinal impairment can be mild or severe ${ }^{(3)}$. Young people are most vulnerable to damage ${ }^{(3)}$. The earliest definitive report was in the eighteenth century and involved five cases of maculopathy due to exposure to the sun, fire or snow ${ }^{(4)}$. The objective of the present study is to report the case of a patient suffering from solar retinopathy and to discuss its disease etiology and prevention.

\section{CASE REPORT}

A.M.R.B., 38, female, white, married, complained of metamorphopsia in the left eye for five months. The patient denied using medication regularly, having any systemic diseases or having a history of abnormal solar exposure.

Upon physical examination, the patient had 20/20 visual acuity in both eyes, including $-4.75 \mathrm{sph}$. $-0.50 \mathrm{cyl}$. at $20^{\circ}$ in the right eye (RE) and $-5.25 \mathrm{sph}$. in the left eye (LE). Biomicroscopy showed no changes in either eye and no fundoscopic changes in the RE, but there were changes in the retinal pigment epithelium (RPE) in the macular area of the LE.

Optical coherence tomography (OCT) was performed that same day and indicated that there was an interruption of the inner hyperreflective layer (I-HRL) and an absence of reflectivity of the underlying layer, which is consistent with solar retinopathy (Figure 1).

The patient returned after 45 days to undergo fluorescein angiography, which was normal (Figure 2). The patient had stable visual acuity and was asked to return in six months to repeat exams. The OCT showed the same alteration in the left eye (Figure 3). The retinography and the retinal fluorescein remained normal (Figure 4).

\section{DISCUSSION}

Solar retinopathy is multifactorial and is dependent on photobiology, personal susceptibility, exposure time and geophysical conditions ${ }^{(5)}$. The incidence of solar retinopathy is low and is not always related to a history of sun exposure ${ }^{(1)}$. The observation of solar eclipses, hallucinogenic drug use and psychiatric disorders can explain most exposures ${ }^{(6)}$. The thermal effect of microscope light or indirect ophthalmoscope light can cause retinal damage similar to that of solar exposure ${ }^{(7)}$. In 1978, three cases of solar retinopathy with minimal exposure were reported as being due to the patients' high

Submitted for publication: March 21, 2013

Accepted for publication: May 23, 2013

Study carried out at Universidade do Oeste do Estado de Santa Catarina. - UNOESC, Campus Joaçaba, (SC), Brazil.

Physician, Universidade do Oeste do Estado de Santa Catarina - UNOESC - Campus Joaçaba (SC),

Brazil.
Medical Student, Universidade do Oeste do Estado de Santa Catarina - UNOESC - Campus Joaçaba (SC), Brazil. Funding: No specific financial support was available for this study.
Disclosure of potential conflicts of interest: R.A.Stock, None; S.L.Savaris, None. E.C.R.Lima Filho,
None; E.L.Bonamigo, None.
Corresponding author: Elcio Luiz Bonamigo. Rua Francisco Lindner, 310 - Joaçaba (SC) - 89600-000
- Brazil - E-mail: elcio.bonamigo@unoesc.edu.br
Ethics Committee: Ruling № 102.613/2012 of the Committee on Ethics in Research at the Uni-
versity of the West of Santa Catarina State (Comitê de Ética em Pesquisa da Universidade do Oeste de Santa Catarina - UNOESC). 


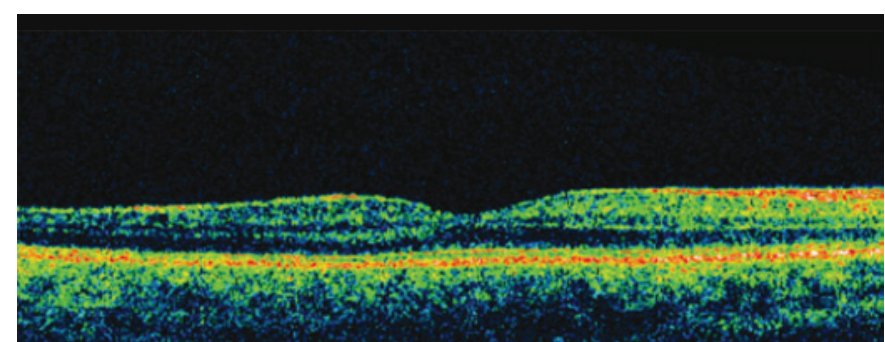

A

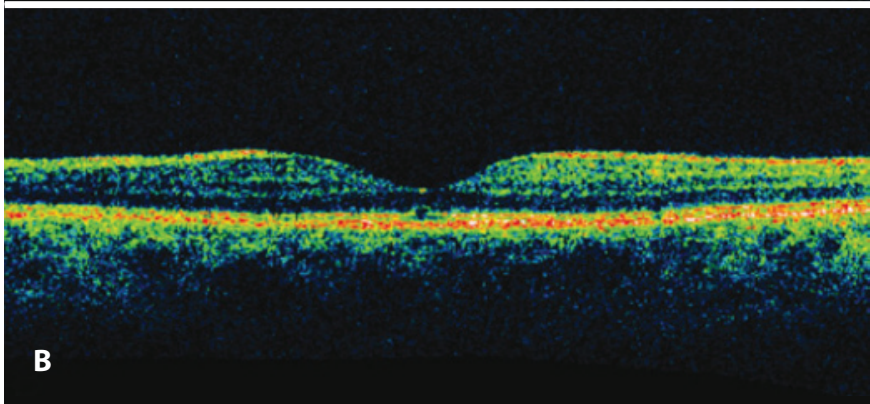

Figure 1. A) Normal optical coherence tomography (OCT) of the right eye. B) Optical coherence tomography $(\mathrm{OCT})$ of the left eye showing an interruption in the inner hyperreflective layer (I-HRL) and an absence of reflectivity of the underlying layer.

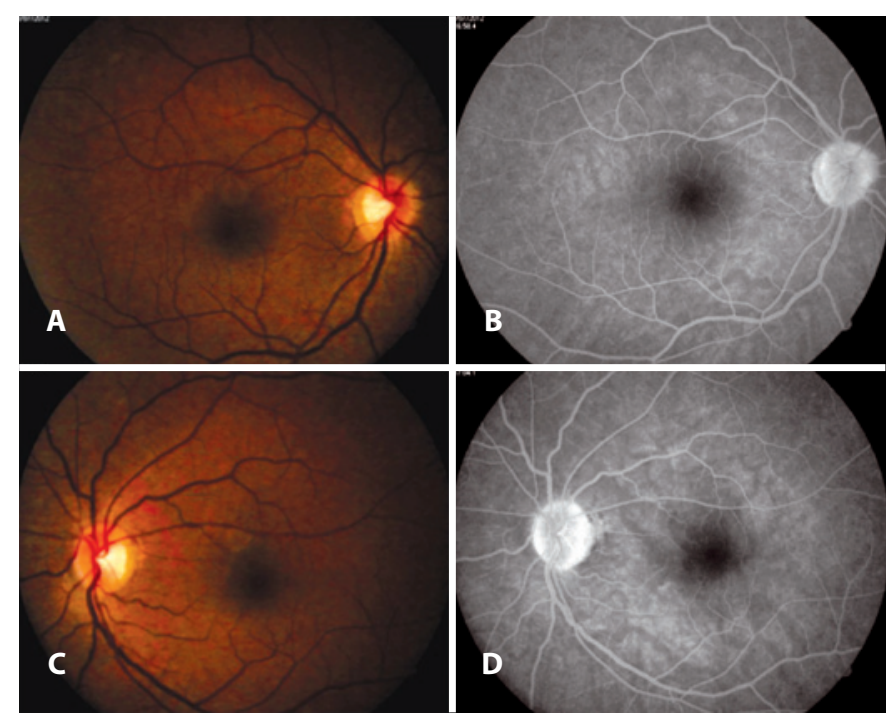

Figure 2. Retinography and normal retinal fluorescein angiogram of the right eye (A and B). Retinography and normal retinal fluorescein angiogram of the left eye (C and D).

susceptibility ${ }^{(8)}$. In the present case report, the patient denied having abnormal light exposure.

The ocular optical system functions as a magnifying glass, converging light rays onto the macula and explaining the generation of photic injury ${ }^{(7)}$. Susceptibility to damage varies between individuals ${ }^{(9)}$. Young people are more vulnerable because of the greater transparency of their lens although their capacity for regeneration is greater ${ }^{(9)}$

Patients exposed to abnormal luminosity may have visual loss or be asymptomatic ${ }^{(1)}$. In case reports of solar retinopathy, symptoms begin a few hours after direct observation of the sun ${ }^{(5)}$. In most cases,
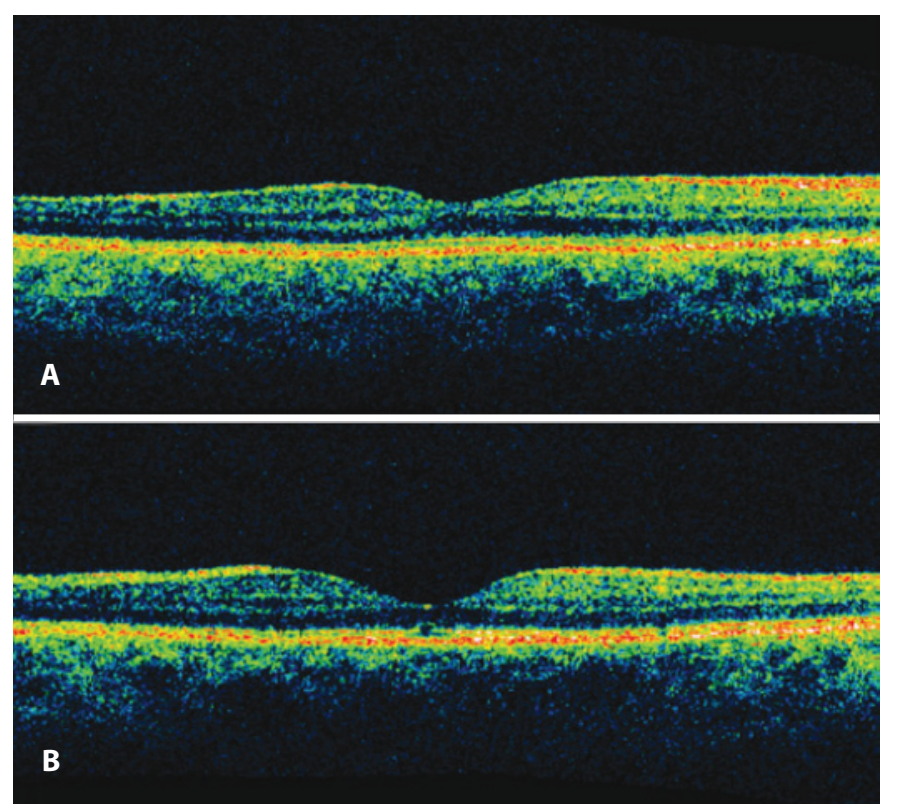

Figure 3. Follow up after six months: A) Normal optical coherence tomography (OCT) of the right eye. B) Optical coherence tomography (OCT) of the left eye showing an interruption in the inner hyperreflective layer (I-HRL) and an absence of reflectivity of the underlying layer.

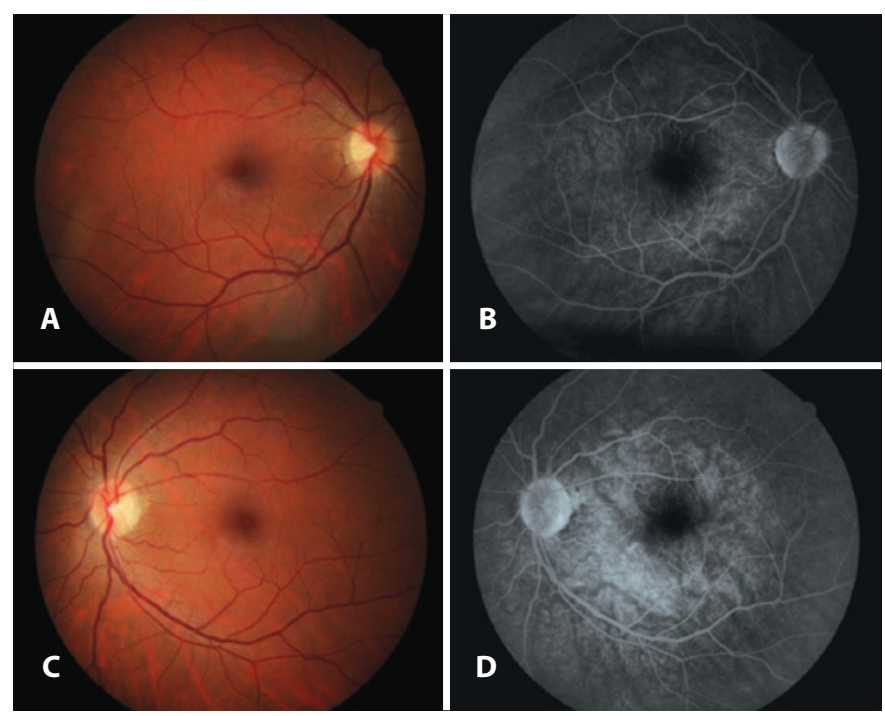

Figure 4. Follow up after six months showing retinography and normal retinal fluorescein angiogram of the right eye (A and B). Retinography and normal retinal fluorescein angiogram of the left eye (C and D).

patients present with asymmetric bilateral impairment and reduced visual acuity from 20/40 to 20/80, which may decline to 20/200 or worse in severe injuries ${ }^{(5)}$. Symptoms including glare, central or paracentral scotoma, migraine and metamorphopsia typically follow exposure ${ }^{(5,7)}$. In the present case report, the patient's only symptom was metamorphopsia.

The macula may appear normal on ophthalmoscopic images immediately following exposure ${ }^{(5)}$. After 24 hours, there may be a loss of the foveal reflex or grayish thickening of the retinal pigment epithelium ${ }^{(5)}$. These symptoms tend to disappear within a week and a yellowish injury appears in the fovea ${ }^{(1,5,10)}$. After 14 days, the lesion is 
replaced by a lamellar or juxtafoveolar defect with well-demarcated reddish irregular edges, which may resolve in mild cases $^{(1,5,9)}$. Some authors consider this lamellar defect of solar retinopathy to be pathognomonic(8).

Fluorescein angiography may indicate early infiltration in the fovea centralis in the acute phase of the disease, and a retinal pigment epithelial window defect may appear at later stages ${ }^{(10)}$. However, in most cases, as in the present case, there is no change ${ }^{(9)}$. The diagnosis can be confirmed using clinical history and a fundoscopy. However, the advent of OCT has helped to both confirm a diagnosis, assess the extent of the lesion and monitor its progression ${ }^{(2,6)}$. In the present case, the OCT examination detected a rupture of the pigment epithelium.

Foveal alterations in solar retinopathy that are diagnosed using third-generation optical coherence tomography (Stratus OCT) are divided into three classes: (I) fragmentation of the inner hyperreflective layer (I-HRL) and fusion of the inner and outer hyperreflective (O-HRL) layers without spaces, which is manifest in the absence of reflectivity; (II) an interruption of the I-HRL and a lack of reflectivity of the underlying layer, which is usually hypo-reflective and corresponds to the photoreceptor outer segment, and the reflectivity of the layer of photoreceptor nuclei, which are located internally or overlying the I-HRL, is preserved; (III) changes in group II combined with a lack of reflectivity in the inner layer of I-HRL, which is normally hypo-reflective and corresponds to the photoreceptor nuclei ${ }^{(2)}$. The present case report was consistent with the pattern of class II solar retinopathy.

Solar retinopathy usually has a favorable prognosis, and visual acuity returns to 20/20 or 20/40 levels within 3 to 9 months ${ }^{(9)}$. Currently, there is no effective treatment, and patients are monitored until they achieve visual stabilization ${ }^{(6,10)}$.

Exposure to sunlight because of observing an eclipse, drug use for religious reasons or microscope and ophthalmoscope light are the main causes of solar retinopathy and are all easily preventable. However, the present case, which was not the result of eye injury based on the angiographic examination or a history of abnormal light exposure, emphasizes the value of OCT in diagnosing solar retinopathy and alerting individuals to the possibility that they are highly susceptible to damage. These results highlight the need to educate individuals about preventive measures and recommend that they reduce the duration of their exposure to light and use protective eyewear with effective filters.

\section{REFERENCES}

1. Comander J, Gardiner M, Loewenstein J. High-resolution optical coherence tomography findings in solar maculopathy and the differential diagnosis of outer retinal holes. Am J Ophthalmol. 2011;152(3):413-9.

2. Farah ME. Tomografia de coerência óptica: OCT. $2^{\text {nd }}$ ed. Rio de Janeiro: Cultura Médica: Guanabara Koogan; 2010.

3. Mainster MA. Solar eclipse safety. Ophthalmology. 1998;105(1):9-10.

4. Saint-Yves C. Nouveau traité des maladies des yeux, les remedes qui y conviennent, \& les operations de chirurgie que leurs guerisons exigent avec de nouvelles decouvertes sur la structure de l'oeil, qui prouvent l'organe immnédiat de la vue. Paris: Chez Pierre-Augustin le Mercier; 1722.

5. Sampaio ER, Casella AM, Farah ME. Retinopatia solar após ritual religioso na cidade de Londrina. Arq Bras Oftalmol. 2004;67(2):271-5.

6. Pinheiro A, Souza EC, Moura FC, Vessani RM, Takahashi W. Estudo com tomografia de coerência óptica em pacientes com retinopatia solar. Rev Bras Oftalmol. 2004; 63(5/6):310-4

7. Riordan-Eva P, Whitcher JP. Oftalmologia geral de Vaughan \& Asbury. $17^{\text {th }}$ ed. Porto Alegre: AMGH; 2011

8. Gladstone GJ, Tasman W. Solar retinitis after minimal exposure. Arch Ophthalmol. 1978;96:1368-9.

9. Zisman M, Nehemy MB. Retinopatia solar: relato de 5 casos. Rev Bras Oftalmol. 1995; 54(9):43-8.

10. Kung YH, Wu TT, Sheu SJ. Subtle solar retinopathy detected by fourier-domain optical coherence tomography. J Chin Med Assoc. 2010;73(7):396-8. 